\title{
Impact of Treatment in Drinking Water Quality at Pannaipatti Purification Plant, Theni District, Tamil Nadu, India
}

\author{
Thamaraiselvi V. Pitchaimani, Nirmala Thivayanathan \\ Research Centre of Zoology, Jayaraj Annapackiam College for Women, Periyakulam, Theni District, Tamilnadu, India \\ Email address: \\ vpthamaraiselvi@gmail.com (T. V. Pitchaimani), principal@annejac.com (N. Thivayanathan)
}

\section{To cite this article:}

Thamaraiselvi V. Pitchaimani, Nirmala Thivayanathan. Impact of Treatment in Drinking Water Quality at Pannaipatti Purification Plant, Theni District, Tamil Nadu, India. Hydrology. Vol. 4, No. 2, 2016, pp. 19-25. doi: 10.11648/j.hyd.20160402.12

Received: February 26, 2016; Accepted: May 12, 2016; Published: May 19, 2016

\begin{abstract}
Water quality is one of the most important criteria to ascertain its suitability for human consumption. An investigation was undertaken to study the physical and chemical properties of untreated and treated drinking water at Pannaaipatti purification plant, Theni District, Tamil Nadu. The physico chemical parameters such as $\mathrm{pH}$, total alkalinity, total hardness, turbidity, chloride, sulphate, nitrate, dissolved oxygen, total dissolved solids and conductivity were analysed. The water samples were clear and odourless. All the parameters of the water samples were within the permissible limit as prescribed by the standard water quality parameters for drinking. Comparatively alkalinity, hardness, chloride, chlorine and total dissolved solids of the treated water were higher than the untreated water. Though all the parameters were within the standard permissible limit for drinking, some of the micro nutrients such as fluoride, magnesium and iron concentration were not recorded.
\end{abstract}

Keywords: Untreated and Treated Drinking Water, Physicochemical Parameters, Water Quality, Purification Plant, Theni District

\section{Introduction}

"No life without water" is a common saying depending upon the fact that water is one of the naturally occurring essential requirement of all life supporting activities. Water is one of the major components of environmental resources [1]. Water is a resource that has many uses, including recreation, transportation, and hydroelectric power, domestic, industrial, and commercial values. Water also supports all forms of life and affects our health, lifestyle, and economic well being. Fresh water is a natural home of innumerable living things, many of them harmless or even beneficial, some of them directly or indirectly harmless to man. The harmness due to environmental pollution that affects the general quality of our health and well being [2]. Limnological investigations on water bodies were aimed to assess the deterioration of water quality due to pollution. Several studies have been made on the limnology of fresh water bodies in India [3, 4]

Fresh water has become a rare commodity due to over exploitation and pollution [5-8]. The water is the foremost requirement of all human beings. River water is one of the most important and widely distributed natural resources which are considered as supplementary resource to meet the domestic, agricultural and industrial requirements. Such rivers are subjected to various physico chemical and biological processes [9].

Although more than three quarters of the earth's surface is made up of water, only 2.8 percent of the Earth water is available for human consumption [10]. At present, approximately one-third of the world's people live in countries with moderate to high water stress and the worldwide freshwater consumption raised six fold between the years 1900 and 1995 more than twice the rate of population growth. Thus, many parts of the world are facing water scarcity problem due to limitation of water resources coinciding with growing population [11].

The potential of various water resources and their quality should be evaluated thoroughly to generate baseline information for the welfare of Society. Further, it is easy for planners and decision makers to take necessary steps 
regarding improvement and management of pollution status.

The demands for quality drinking water had changed considerably with the development in olden days, the only requirement of drinking water was that it should be free flowing and non turbid. With increasing industrialization, urbanization, and growth of population, India's environment has become fragile and has been causing concern [12]. Urbanization has direct impact on water bodies as the settlement takes place around the vicinity of water bodies and due to lack of space, people have tendency to encroach upon the lake [13].

Water in nature is seldom totally pure. Almost $70 \%$ of the water has become polluted due to the discharge of domestic sewage and industrial effluents into natural water sources. Increase in human population and urbanization in recent years resulted in gradual deterioration of water quality. The uniqueness of the water body has deteriorated as it is getting thickened with pollutants. It is estimated that each year 10 million people die from contaminated drinking water. According to WHO, [14] organization about $80 \%$ of all diseases in human as caused by water. Atlas and Bartha, [15] considered that bacteria play an important role in global ecosystems which are major factors in controlling the quality of water and are fated determinants of pollution released into the environment.

Water plays an essential role in human life. Although statistics vary, the World Health Organization reports that approximately $36 \%$ of Urban and $65 \%$ of rural Indian's were without access to safe drinking water [16]. Water scarcity and the fast decline of aquatic biodiversity are indicators of ineffective implementation of water protection policies $[17 \&$ 18]. Sustainable and optimal use of natural resources is imperative in any country due to its concomitant economic implications such as industrial and population growth, infrastructure and development demands [19].

Climate change will accentuate shortages of freshwater in many parts of the world during the next 20 years and the seasonal availability of it is uncertain [20]. The terrestrial water cycle has been significantly altered by the construction and operation of water engineering facilities. Reservoirs, in particular have fragmented and transformed the Worlds Rivers. The last century saw a rapid increase in large reservoir building. By the end of 20th century, there were 45,000 large dams in over 140 countries [21-23].

Ground water is the chief source of drinking water in India and this is only $0.61 \%$ of the total available water on the earth [24]. Pollution of drinking water sources in rural areas may involve seepage from broken septic tanks, pit latrines and runoff water carrying fertilizers, pesticides, herbicides, fungicides and fecal matter [25 \& 26]. Water pollution results in transmission of infectious diseases such as dysentery, cholera, diarrhea, typhoid, shigellosis, salmonellosis, and varieties of other bacteria as well as fungi, viral, and parasitic infection [27 \& 28].

The transmission of diseases through drinking water is one of the primary concerns for safe drinking water. Fecal pollution of drinking water may introduce a variety of intestinal pathogens which may cause diseases from mild gastroenteritis to severe and sometimes fatal dysentery, diarrhea, cholera, typhoid, hepatitis, giardiasis etc., Crown, [29 \& 30] and Wanda, (2006). The chemistry of water reveals much about the metabolism of the ecosystem and explains the general hydro - biological relationship [31].

Therefore it is necessary that the quality of drinking water should be checked at regular intervals, because of the use of contaminated drinking water, human population suffers from varied water borne diseases. Hence the present study is intended to evaluate the Impact of Treatment in Drinking Water Quality at Pannaipatti Purification Plant, Theni District.

\section{Materials and Methods}

\subsection{Description of the Study Site}

Vaigai reservoir is located at $70 \mathrm{~km}$ from Madurai and lies between $9^{\circ} 30^{\prime}$ and $10^{\circ} 10^{\prime}$ North latitude and $77^{\circ} 10^{\prime}$ and $77^{\circ} 40^{\prime}$ East longitude. The stored water in the reservoir is used for irrigation, power generation and drinking water of Madurai city. The catchment area of Vaigai reservoir is $2253.30 \mathrm{~km}^{2}$, the entire catchment lies in Madurai and Theni districts of Tamilnadu. The catchment area comprises Cumbam valley, Varushanadu valley, Varushanadu hills and Western Ghats. The data were collected from Pannaipatti Purification Plant, Theni district, Tamil Nadu.

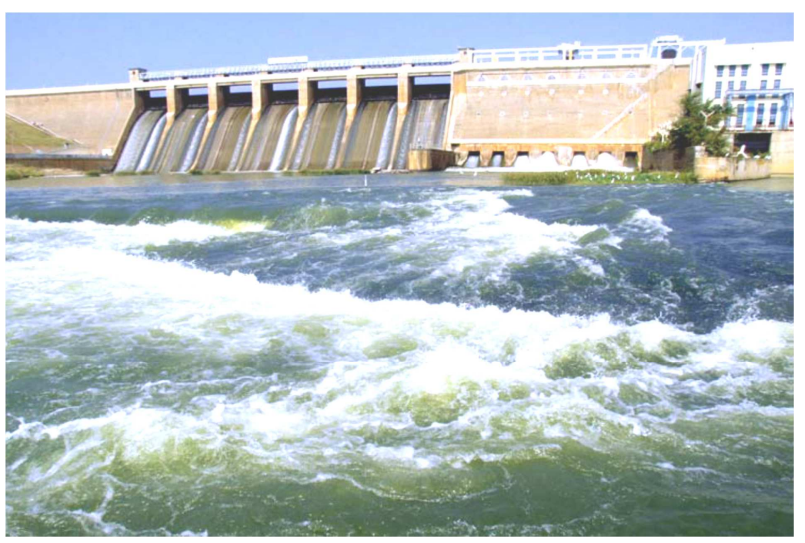

Plate 1. Vaigai Reservoir.

\subsection{Sample Collection and Preservation}

The study was conducted during the early hours of the day from January, 2015 to December, 2015. For the present investigation the water samples were collected in sterilized plastic bottles every month in the early hours.

\subsection{Analysis of Water Samples}

Colour, Odour, $\mathrm{pH}$ and Temperature of the water samples were measured on the sampling spot by water analyzer kit. Total Alkalinity, total hardness, magnesium, calcium and chloride contents were analyzed by titrimetric methods in the laboratory following the standard methods as prescribed by APHA, [32]. 


\section{Results and Discussion}

The physico chemical parameters of the untreated and treated water samples of pannaipatti water purification plant, Theni District, were analysed for its suitability for drinking purpose. The data were compared with the drinking water standards of ISI, BSI and WHO. The data revealed that there was considerable variation in the analysed samples.

The colour of the untreated and treated water samples was clear and colourless. As per WHO, drinking water must be colourless and clear. In 2006, Prakash and Somashekar, [33] reported that the presence of colouring material in water is due to constant mixing with organic debris and the presence of high concentration of iron in it.

The turbidity of untreated water sample was high in December (8.4 NTU) and it was nil in the treated water except in December (0.2 NTU). Turbidity was in negligible concentration as in the study of Nirmala et al. Delphine Rose et al. and Jeyaseli et al. [34 - 36]. Akaka and Thombre, [37] also recorded similar results in drinking water samples at Buldona District.

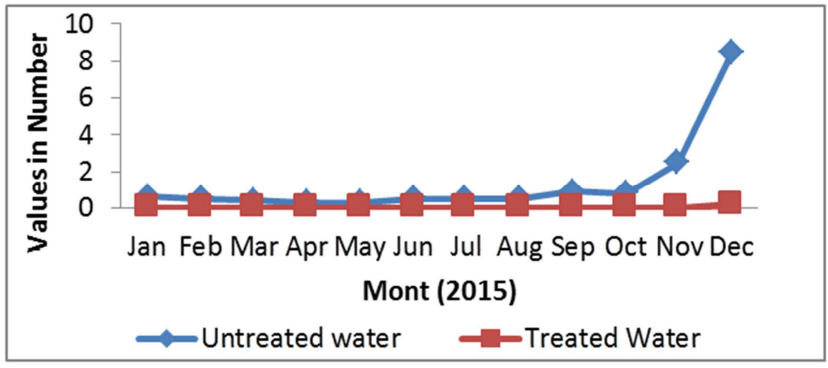

Figure 1. Turbidity of untreated and treated Water samples at Pannaipatti purification plant Theni District.

Total dissolved solids of untreated water and treated water were high in July and low in January. In treated water, the total dissolved solids were higher than the untreated water (Figure 1). In the present study the total dissolved solids were lower than the standard values where as Nirmala et al. and Delphine Rose et al. [34 \& 35] investigated higher values of total dissolved solids in the drinking water samples of Theni and Dindigul District. Similar observations were made by Pavendan et al.; Edimech et al.; Ezeribe et al.; Anilkumar et al. and Karthikeyan and Elango [38-41].

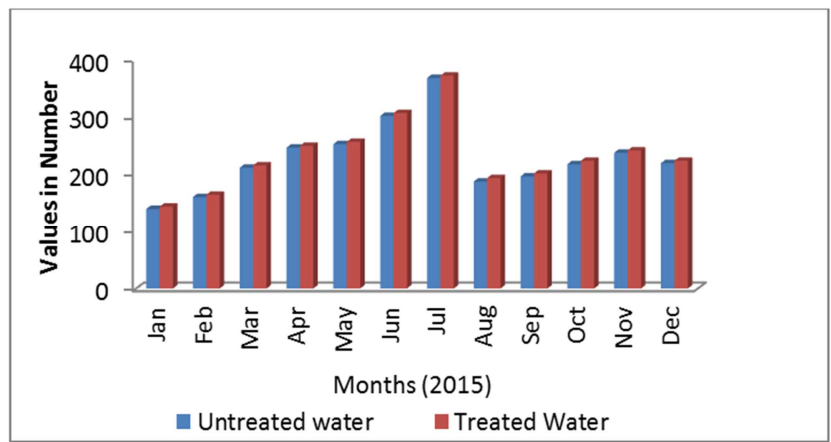

Figure 2. Electrical Conductivity of untreated and treated Water samples at Pannaipatti purification plant Theni District.
The values of electrical conductivity were within the standard permissible limit. The electrical conductivity was high in July and low in January in both the water. The electrical conductivity of the treated water was higher than the untreated water (Figure 2). Similar observations were made by Anilkumar et al. [41] and Karthikeyan and Elango [42]. Srinivas [43]; Arul [44]; Achuthan Nair [45] opined that the higher values of electrical conductivity in ground water is due to high dissolved solids and has a direct bearing on the percentage of total solids. The findings were in concordance with the values of Nirmala et al. [34] and Jayaseeli et al. [36]. In 2013, Dinesh and Rajesh [46] observed decrease in values of Conductance in the water sample which clearly indicates that the water of this region is polluted. Saxena and Kaur; Sharma and Singh; Werkneh et al. [47-49] observed that higher electrical conductivity regulates higher total alkalinity of water.

The $\mathrm{pH}$ of the water samples ranged from $7-7.3$ in treated water and $7.2-7.5$ (Figure 3) and they were within the permissible limits. It indicates the presence of very weak basic salts [41, $48 \& 50]$.

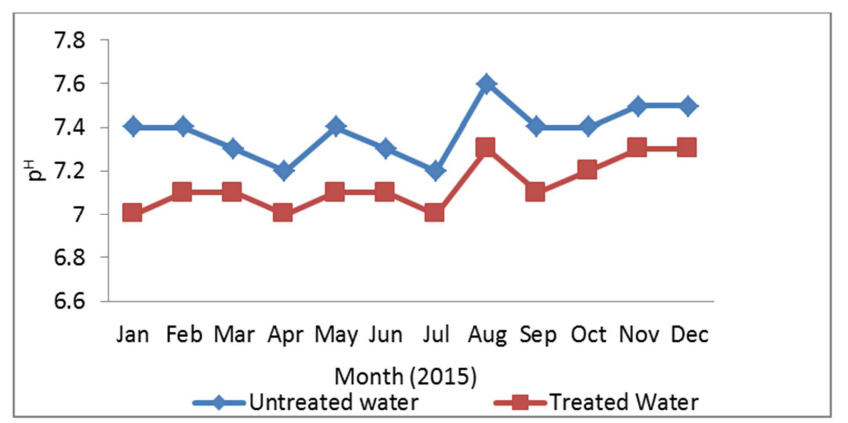

Figure 3. $p H$ of untreated and treated Water samples at Pannaipatti Purification Plant, Theni District.

The alkalinity of the sample in the present study was within the standard limits of BIS for drinking water as in the study of Shova, [50]. To compare with the total alkalinity value in treated water was lower than the untreated water (Figure 4). Nirmala et al. [34]; Pavendan et al. [38] and Anilkumar et al. [41] observed higher values of alkalinity in drinking water of Theni District and Tiruchirapalli District respectively.

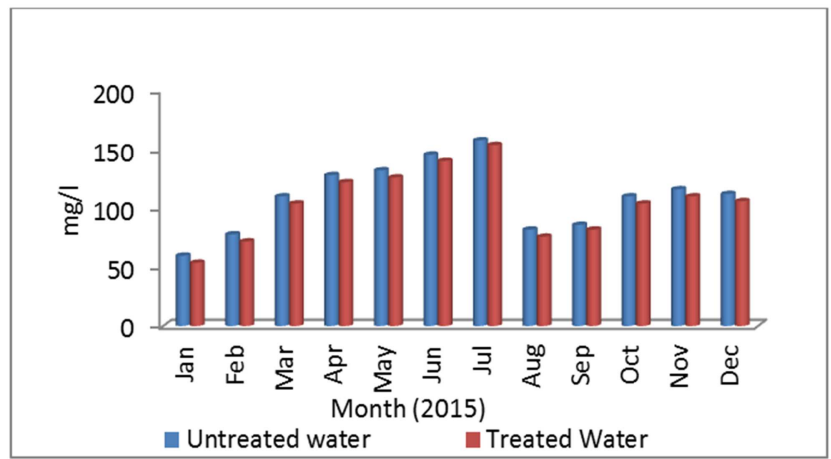

Figure 4. Total Alkalinity of untreated and treated water samples at Pannaipatti Purification Plant, Theni District. 
In the present investigation the values of total hardness ranged from $70-164 \mathrm{mg} / \mathrm{l}$ in untreated water and treated water. Total hardness of the present investigation was within the permissible limit (Figure 5). In both the samples the hardness of the water was high in July and low in February. Hardness in water is caused by metabolic ion dissolved in water [51]. As the water has higher alkalinity in July, the value of hardness also increased in July, which is indicative of the presence of carbonates and bicarbonates. Similar observations were made by Ashish and Yogendra [52]; Nirmala et al. [34] and Pavendan et al. [38].

The nitrate concentration of the water samples were within the prescribed limit. The concentration of nitrate in the untreated water samples was higher than the treated water samples. Nitrate value of water sample was observed high in January, June, July and December and it was low in May in both the untreated and treated water sample (Table 1). Similar observations were made by Aremu et al. [53];
Ezeribe et al. [40]; Balamurugan and Sivakumar [54]; Robert [55]; Nirmala et al. [34]; Delphine Rose et al. [35] and Pavendan et al. [38]. Higher values of nitrate were observed by Sivamanikandan and John [56].

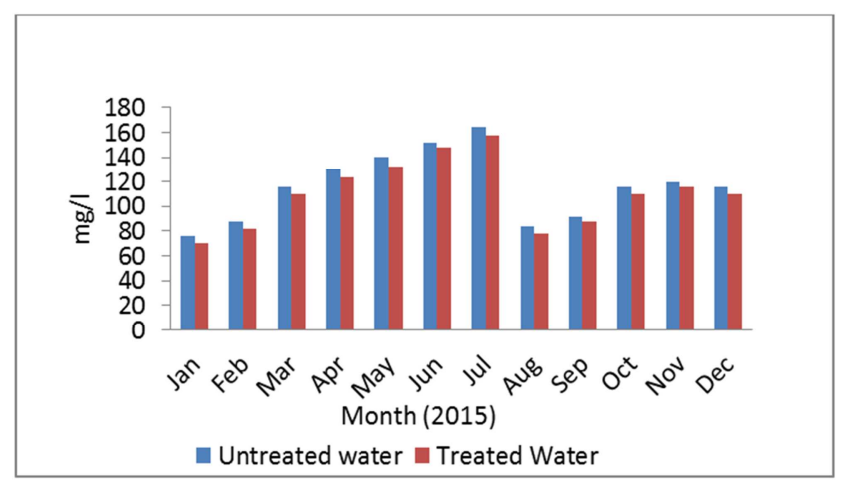

Figure 5. Total Hardness of untreated and treated water samples at Pannaipatti Purification Plant, Theni District.

Table 1. Micro Nutrients of untreated and treated water samples at Pannaipatti Purification Plant, Theni District in 2015.

\begin{tabular}{|c|c|c|c|c|c|c|c|c|}
\hline \multirow{2}{*}{ Months } & \multicolumn{2}{|l|}{ Nitrate } & \multicolumn{2}{|l|}{ Chloride } & \multicolumn{2}{|l|}{ Sulphate } & \multicolumn{2}{|l|}{ Chlorine } \\
\hline & Untreated & Treated & Untreated & Treated & Untreated & Treated & Untreated & Treated \\
\hline Jan & 4 & 4 & 13 & 15 & 4 & 4 & 2 & 3.7 \\
\hline Feb & 3 & 3 & 11 & 13 & 4 & 2 & 2 & 3.7 \\
\hline Mar & 3 & 3 & 15 & 17 & 5 & 2 & 2 & 3.7 \\
\hline Apr & 3 & 3 & 12 & 14 & 4 & 2 & 2 & 3.7 \\
\hline May & 2 & 2 & 16 & 18 & 3 & 2 & 1.8 & 3.2 \\
\hline Jun & 4 & 4 & 18 & 20 & 4 & 2 & 1.2 & 3.2 \\
\hline Aug & 4 & 4 & 18 & 20 & 5 & 3 & 1.2 & 3.2 \\
\hline Sep & 3 & 3 & 18 & 20 & 5 & 2 & 1.2 & 3 \\
\hline Oct & 3 & 3 & 17 & 18 & 4 & 2 & 1.2 & 3 \\
\hline Nov & 3 & 3 & 15 & 16 & 5 & 2 & 1.2 & 2.8 \\
\hline Dec & 4 & 4 & 17 & 19 & 5 & 3 & 1.2 & 2.9 \\
\hline
\end{tabular}

The permissible amount of chloride in drinking water sample was $200 \mathrm{mg} / \mathrm{l}$. The water samples taken for the study were within the permissible limit. Chloride was high in June, August, and September in untreated water sample where as it was high in June, August and September in treated water. The value was low in February in both the water samples (Table 1). Variation in chloride content in Vaigai river water sample was observed by Alikhan and Nazar, [57]. This may be due to addition of chloride during the process of treatment. Similar observations were made by Jeyaseeli et al. [36] at Nilakottai Taluk, Shova, 2014 [50] at Katmandu, whereas Balamurugan and Sivakumar, [54] reported higher concentration of chloride in the drinking water samples at Madurai District.

The values of sulphate were within the permissible limit. Maximum concentration of sulphate in the water sample was observed in untreated water sample and the minimum concentration of sulphate was observed in treated water sample (Table 1). In treated water sample except for January, the sulphate value remains the same throughout the year. This is on a par with the observation made by Vanitha and Shunmugavelu [58].

Untreated water contained low concentration of chlorine whereas, high amount of chlorine content was observed in treated water and they are not exceeding the permissible limit (Table 1). This may be due to the addition of chlorine during the purification process. Muegge [59] summarized the effect of heavily chlorinated water on human population exposed deriving varying periods.

The presence of dissolved oxygen in the untreated water varies markedly (Figure 6). After treatment, the dissolved oxygen in the water sample was reduced. The reduction or changes in the dissolved oxygen content of water sample depends upon the temperature, seasonal changes prevailing in the particular area [54].

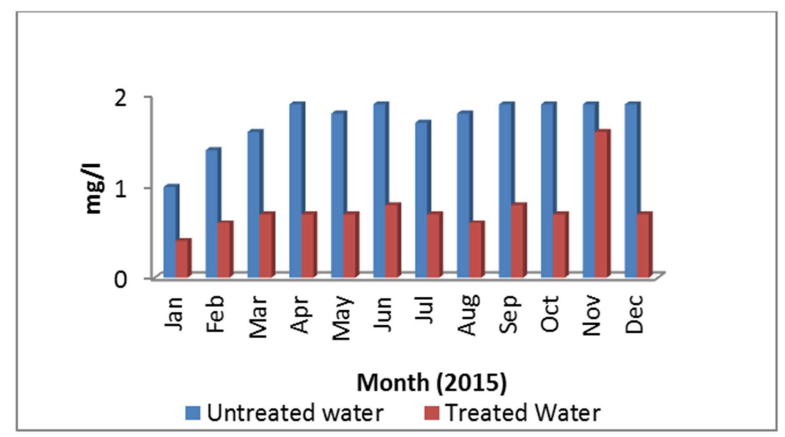

Figure 6. Dissolved Oxygen of untreated and treated water samples at Pannaipatti Purification Plant, Theni District. 


\section{Conclusion}

Conclusively, the present study reveals that, the drinking water quality parameters are well within the permissible limit. From the observed results it was investigated that, though all the parameters were within the standard permissible limit for drinking, some of the micro nutrients such as fluoride, magnesium and iron concentration were not reported and there is a lacuna in the report. This calls for active need for water management which requires water quality analysis as the initial step. Therefore it is suggested to monitor the water quality periodically and to analyze all the macro and micro nutrients in water before and after treatment in the laboratory to prevent some diseases such as coronary heart disease, skeletal fluorosis, stained and mottle teeth etc.

\section{Acknowledgement}

Authors express their deep sense of gratitude to Jayaraj Annapackiam College for Women (Autonomous), Periyakulam for providing the laboratory facilities. Authors acknowledge the immense help received from the scholars whose articles are cited and included in references of this manuscript. We are grateful to our research supervisor for useful discussions during the course of the study and preparation of the manuscript.

\section{References}

[1] S. T. Efe, "Urban warming in Nigerian cities". The case of warri metropolis, African Journal of Environmental Studies 2002, vol. 2, 2, pp. 6-7.

[2] S. Parimala R. Jaganathan S, Geetha and S. Balasubramaniam, "Statistical correlation between dissolved oxygen levels and environmental factors in a tropical lakes", J. Ecobiol., 1994, vol. 6,4 , pp. 265-270.

[3] M. N. Naganandini, and S. P. Hosamani., "Ecology of certain inland waters of Mysore district, Occurrence of Cyanophycean bloom at Hosakere lake, Pollution Research", 1998, 17, 2, pp 123-125.

[4] K. Patel Niroj and B. K. Sinha, "Study of the pollution load in the Ponds of Burla area near Hirakund dam at Orissa", Journal of Environmental pollution, 2000, 5, 2, pp. 157-160.

[5] B. B. Ghose and A. K. Basu, "Observation on estuarine pollution of Hoogly by the effluents from a chemical factory complexat Reshase, West Bengal. Env. Health.” 10: 1968., pp. 209-218.

[6] D. P. Gupta Sunita and J. P. Saharan "Physiochemical Analysis of Ground Water of Selected Area of Kaithal City (Haryana) India”, Researcher, 1996, vol. 1, 2, pp. 1-5.

[7] P. R. Patil, K. S. Patil and A. D. Dhande "Studies on drinking water quality in Bhusawal corporation water supply", Int. J. Environ. Protec, 2002, vol. 22, 2, pp. 161-164.

[8] R. P. Matur Singh, and Mathur, P. (2005), Investigation of Variation in Physico-Chemical Characteristics of a Fresh
Water Reservoir of Ajmer city, Rajasthan. Indian Journal of Environmental Science, 9, pp 57-61.

[9] R. K. Trivedi A. Y. Khatavkar Kulkarni and A. C. Shrotri, "Ecology and pollution of River Krishna in Maharashtra", Ministry of Environment and Forests", Government of India 1990.

[10] M. B. Iskandar "The effectiveness of biofilter as a treatment for domestic wastewater", University Malaysia Pahang (thesis), 2010.

[11] UNEP. Global Environmental Outlook. United Nations Environment, 2000.

[12] U. K. Mohapatra, and B. C. Singh, Indian Journal of Environmental Health, 1999, vol. 41, 2, pp. 115-120.

[13] A. Khan, Bhatnagar and R. Saxena, "An introduction of Bhopal Lakes". In S. K. Kulshreshtha (Ed.), Proc. nat. symp. present, past and future of Bhopal lakes, 1988, pp. 7-10.

[14] WHO "Guidelines for Drinking Water Quality". First Addendum to 3rd Edition, vol. 1. Geneva. Bacteriological and Physico-Chemical Quality of Main Drinking Water Sources Pol. J. Environ. Stud. 2013, Vol. 22, 3, pp. 825-830.

[15] R. M. Atlas and R. Bartha "Microbial ecology: Fundamentals and Applications", 3rd Edition, Redwood city, Benjamin, 1993.

[16] WHO "guidelines for drinking water quality" 2nd edition. Recommendation. World Health organization Geneva, 2009, 1, pp. 30-113.

[17] D. J. Rapport, C. Gaudet and P. Calow, "Evaluating and monitoring the health of large ecosystems", Springer Verlag, Berlin, Heidd berg. New York, USA, 1995.

[18] N. Johnson C. Revenga and J. EcheVeria "Managing water for People and Nature". Science 2001, vol. 292, pp. 1071-1072.

[19] DEAT - "Department of Environmental Affairs and Tourism", Inland water - factors affecting availability and water quality 2005.

[20] C. J. Vorosmatry, P. Green, J. Sahsbury and R. Lammers, "Global water resources vulnerability from climate change and population growth" Science, 2000, 289 5477: pp. 284288.

[21] World commission on Dams and development: "A new framework for decision making". The report of the world commission on Dams. Earthscan Publications Ltd., London. 2000 .

[22] C. J. Vorosmatry, and D. Sahagian, "Anthropogenic disturbance of terrestrial water cycle", Bioscience, 2000, 50, 9: pp. 753-765.

[23] S. Postal, B. D. Richter and R. W. John, "Rivers for life: Managing water for people and Nature". Island Press Washington D. C, 2003.

[24] R. Singh, Archives of Applied Science Research., 2011, vol. 3, 1 , pp. $444-449$.

[25] E. E. Geldreich, "The Bacteriology of Water". In: Coller, L., Balows, A. and Sussman, M. editors. Topley and Wilson's Microbiology and Microbial Infections, 2005, $9^{\text {th }}$ ed. pp 351363. 
[26] A. I. Hart, N. Zabbey, "Physicochemical and benthic fauna of Woji Creek in the Lower Niger Delta, Nigeria". Environ. Ecol. 2005, 23, 2: 361-368.

[27] WHO-Water Sanitation and Health. "Water related diseases", 2003.

[28] P. Pavan Kumar Pindi, Raghuveer Yadav, Ashwitha Kodaparthi, "Bacteriological and Physico-Chemical Quality of Main Drinking Water Sources", Pol. J. Environ. Stud. Vol. 22, 2013, pp. $3825-830$

[29] G. F. Crown, "Water-borne Diseases in the United States". CRC Press, Inc, 1986.

[30] E. Wanda, D. C. Jerry and A. M. Beverly, "Bacterial in Drinking Water", 2006.

[31] Basavaraja Simpi, S. M. Hiremath, K. N. S. Murthy, "Analysis of Water Quality Using Physico-Chemical Parameters Hosahalli Tank in Shimoga District", Karnataka, India, Global Journal of Science Frontier Research, 2011, 11, 3.

[32] APHA "Standard methods for the examination of water and wastewater", $17^{\text {th }}$ ed. Washington, DC, American Public Health Association, 2005.

[33] K. L. Prakash and R. K. Somashekar, "Groundwater quality Assessment on Anekal Taluk, Bangalore Urban district, India" J. Environ. Biol., 27, 2006. pp. 633-637.

[34] T. Nirmala, P. Pavatharani and M. R. Delphine Rose, "World Quality Assessment in Theni District, Tamil Nadu, India", J. Aqua., Biol., 2010, 25, 1, pp. 66-68.

[35] M. R. Delphine Rose, T. Chitravalli, A. Jayaseeli, T. Nirmala and A. Thaddeus, "Physico chemical status of ground water in Dindigul district, Tamilnadu" Aquacult., 2007, Vol. 8, 1, pp. 133-137.

[36] A. Jayaseeli, K. S. Priya, M. R. Delphine Rose, T. Nirmala and M. Narayanan, "Critical analysis of ground water quality of Nilakkotai taluk of Tamilnadu", India. J. Curr. Sci., 2006, Vol. 9, 2, pp. 931-934.

[37] Akaka and Thombre, Physico chemical parameters of drinking water samples at Buldona District, M. Sc. Thesis, 2006.

[38] P. Pavendan, S. Anbuselvan and C. Sebastian rajasekaran, "Physico Chemical and microbial assessment of drinking water from different water sources of Tiruchirappalli District, South India", Pelagia Research Library European Journal of Experimental Biology, 2011, Vol., 1, 1, pp. 183-189.

[39] P. O. Edimeh, Eneji, I. S., Oketunde, O. F. and R. Shaato, "Physico-chemical parameters and some Heavy metals content of Rivers Inachalo and Niger in Idah, Kogi State", Journal Chemical Society Nigeria, 2011, Vol., 36, 1, pp. 95101.

[40] A. Ezeribe, I. Oshieke, K. C. and A. Jauro, "Physico Chemical Properties of Well Water samples from some villages in Nigeria with cases of stained and mottle teeth", Science World Journal, 2012, Vol., 7 No 1 pp. 1-3.

[41] N. G. Anil Kumar, S. Bhawsar, S. Khandelwal, S. Sherebano. S. Sakir, S. Ahuja, M. Pathak, R. K. Hanote, S. R. Gayakwad and K. Khasdeo, "Physico-Chemical Parameters Apply to Analysis of Drinking Water from some selected area of Betul District, Madhya Pradesh", 2013, Vol. 3, 4, pp. 1109-1114.
[42] Karthikeyan M. 1, Elango K. P. "Chemometric Analysis of Water Quality Parameters of Dindigul District- A Seasonal Variation Study", Int. J. Res. Chem. Environ. 2015, 5, 2 pp. 44-54.

[43] C. H. Srinivas, Piska Ravi Shankar, C., Venkateshwar, M. S. Satyanarayana Rao, and R. Ravider Reddy, "Studies on ground water quality of Hyderabad" Pollution Research, 19 (2), 2000, pp. 285-289.

[44] P. Arul, "A text book of ground water Dhanam Agency, Tamil Nadu, India", 2000.

[45] G. AchuthanNair, A. I. Mohammad. and M. M. Fadiel, "Physico- Chemical parameters and correlation coefficients of groundwater of North-East Libya". Poll. Res., 24 (1): 2006, pp. 1-6.

[46] A. Pund Dinesh and P. Ganorkar Rajesh, "Study of Some Physicochemical Parameters of Drinking Water Sources in Tembhurkheda and Jarud Region Dist. Amravati, MS, India", International Research Journal of Environment Sciences, Vol. 2, 10, 2013, pp. 93-95.

[47] Neetu Saxena and Harinder Kaur. "Evaluation of ground water quality of Bareilly city", Jr. Indus. Pollution control. 2003, Vol. 19, pp. 169-174.

[48] S. K. Sharma and C. P. Singh Chandel, "A study on the ground water pollution of Amer and Bharath blocks of Jaipur district, Rajasthan”, Aquacult., 2005, Vol., 6, pp. 197-204.

[49] Adhena Ayaliew Werkneh, Belay Zimbelachew Madhanit, Angaw Kelemework Abay and Jemal Yimer Damete, "Physico chemical analysis of dirnking water quality at Jigjiga City, Ethiopia", American Jounal of Environemtal Protection Vol. 4, 1, (2015), pp. 29- 32.

[50] Tamrakar Chirika Shova, Evalution of Physico chemical characteristics of Drinking Water Supply in Kathmandu, Nepal, Res. J. Chem. Sci. Vol. 4, 4, 2014, pp. 33-36.

[51] M. A. Shivasankaran, "Hydro geochemical assessment and current status of pollutants in ground water of Pondicherry region", South India, Ph.D. Thesis, Anna University, Chennai. 1997.

[52] Ashish Kumar and Yohendra, "Water Quality of River Kosi and Rajera System at Rampur" Journal of Chemistry, 2013, pp. 1-4.

[53] M. O. Aremu, O. Olaofe, P. P. Ikokoh, and M. M. Yakubu, "Physicochemical characteristics of strem, well and borehole water soures in Eggon, Nasarawa State, Nigeria", Journal Chemical Society Nigeria, 2011, Vol., 36, 1, pp. 131-136.

[54] C. Balamurugan, R. Sivakumar, "The seasonal variation of water quality parameters in Vaigai River at Madurai, Tamilnadu, India", International Journal of Computer \& Organization Trends 2015, Vol. 19, pp. 2249-2593.

[55] J. W. Robert, Water Clinic Nitrate, Sulphates. Retrieved 5 June, 2006.

[56] Sivamanikandan and John, "Impact of physic chemical parameters on bacterial population in Mullaiperiyar River wter Theni dististict, Tamilnadu, India”, African Journal of Microbiology Research, Vol. 9, 1, 2015, pp. 26-32. 
[57] S. Niham Ali Khan and A. Mohamed Nazar, "Studies on the Fresh water inflows and Hydrographic variables in the Vaigai Reservoir Theni District, Tamil Nadu", International Journal of Advanced Research in Management and Social Sciences, 2013, vol. 4. pp. 1-10,

[58] G. Vanitha. M. Shunmugavelu, "Hydrochemistry and
Environmental Status of Vaigai River Water in Tamil Nadu, India", International Journal of Engineering Research and Applications Vol. 2, Issue 5, 2012, pp. 1942-1946.

[59] O. J. Muegge, "Physiological effects of heavily chlorinated drinking water", Journal of the American Water Works Association, 1956, 48, pp. 1507-1509. 